\title{
Reluctant Donors? The Europeanization of International Development Policies in the
}

\author{
New Members ${ }^{1}$ \\ Simon Lightfoot ${ }^{\mathrm{a}, 2}$ and Balázs Szent-Iványi ${ }^{\mathrm{b}}$ \\ ${ }^{a}$ University of Leeds, Leeds, United Kingdom \\ School of Politics and International Studies (POLIS) \\ Woodhouse Lane, LS2 9JT, Leeds, UK \\ ${ }^{b}$ Corvinus University of Budapest \\ Department of World Economy \\ Fovam ter 8, Budapest H-1093 Hungary
}

\begin{abstract}
The EU played an instrumental role re-starting the international development policies in Central and Eastern European member states, but questions remain about how far this policy area has been Europeanized since accession. Focusing on the Czech Republic, Hungary, Poland and Slovakia, the paper investigates why the new donors have been reluctant to adopt the EU's development acquis more fully. The paper traces the process of the EU's development policy rulemaking and subsequent national rule implementation to understand the socialization opportunities these processes offer. The conclusions reveal thrre reasons why socialization has been weak: (1) perceptions among the new member states on the development acquis' procedural legitimacy; (2) low domestic resonance with the development acquis; and (3) inconsistencies in the activities of norm entrepreneurs. The paper contributes to our understanding of development policy in the EU, in particular how decision making takes place within the Council and its Working Groups post enlargement.
\end{abstract}

Keywords: new member states, international development cooperation, foreign aid, Europeanization, socialization

\footnotetext{
${ }^{1}$ The authors gratefully acknowledge the support of the EU's Marie Curie program (project INDEPNEW). We are also grateful to all the government, EU officials and NGO representatives who agreed to be interviewed. The following people read and commented the paper: Charlie Burns, Monika Hellmeyer, Jan Orbie, Michael Smith and Peteris Timofejevs-Henriksson. Their comments were invaluable, as were the helpful and insightful comments from three anonymous referees. Versions of this paper were presented at the $40^{\text {th }}$ UACES Annual Conference, Bruges, 6-8 September 2010, the $13^{\text {th }}$ EUSA Biennial Conference, Baltimore, May 9-11, 2013 and the $8^{\text {th }}$ Pan-European Conference on International Relations, Warsaw, 18-21 September 2013, alongside various seminars and workshops. Thanks to all the participants who commented at these events. The views expressed here are our own, as are any mistakes.

${ }^{2}$ Corresponding author. Email: s.j.jightfoot@leeds.ac.uk.
} 


\section{Introduction}

Accession to the European Union has had profound influences on official development assistance (ODA) in a number of member states like Ireland, Spain or Austria (see contributions in Hoebink and Stokke, 2005), with membership resulting in a range of changes from the creation of a policy from scratch to the scaling up of aid commitments. The situation in the Central and Eastern European (CEE) new member states (NMS) is similar, as without EU accession conditionality this policy is unlikely to have existed in the NMS. The EU clearly articulated that its members, as part of the developed world, have the responsibility to provide aid to developing countries, and the CEE countries duly created their respective bilateral ODA policies between 2001 and 2003, with Romania and Bulgaria following suit after 2007. While the EU can clearly be credited with pushing the creation of these policies, it is difficult to argue that it had much influence on the course these took after the CEE countries became members; therefore post-accession compliance needs further study.

The aim of the paper is to explain the 'reluctance' four of the NMS (the Czech Republic, Hungary, Poland and Slovakia) have shown in approximating their ODA policies to the EU's acquis communautaire in development policy since their accession. These four states were chosen for a variety of reasons; their links through the Visegrád group, their similar histories of development policy under Communism, and their similar policy trajectories over the past 10 years. The paper focuses on similarities between the four states rather than offer a comprehensive comparative study. Although the EU has provided limited (if any) material incentives for the NMS in this regard, one may still argue that the dense interaction setting between the NMS and the EU institutions in case of development policy should have led to some degree of socialization. Therefore, Europeanization, which has frequently been employed to explain both political and policy reform in candidate countries (Sedelmeier, 2011) and also compliance with EU law in the NMS (Epstein and Sedelmeier, 2008), is used as a framework. While the rational model of Europeanization has traditionally been the preferred framework to explain the extent of compliance with EU legislation in both settings (although with variations among policy areas), the area of development policy constitutes an ideal case study to examine the relevance of social learning for several reasons. First, there is very little legally binding development acquis and thus little possibilities for direct conditionality. Second, the fact that the EU's development acquis aims at increasing the effectiveness of foreign aid in terms of poverty reduction grant it a certain moral force, which could be conducive to socialization. While the paper itself does not wish to take any 
normative stance on how appropriate the EU's development acquis is in terms of poverty reduction, or that 'more EU' in ODA policy leads to greater effectiveness, there is a global consensus on ODA policy reforms similar to those embodied in the acquis. Third, there are dense interactions between member state officials and the EU institutions on development policy issues and fourth, there is a strong presence of potential norm entrepreneurs in the policy area, which try to exert normative pressure on governments.

The paper concentrates on explaining why socialization has thus far proven inadequate in promoting substantial change in the ODA policies of the four NMS by examining how the scope conditions for effective socialization have played out in the past decade. The hypothesis of the paper is that an unconducive environment for socialization weakens long term compliance with the EU's development acquis in the NMS. Process tracing, a method widely employed in the EU literature (see Checkel, 2001) is used to understand the possibilities offered for socialization in the process through which the EU's development acquis is made and later implemented in the four national capitals. The paper concludes that several factors in this process hinder socialization. The four NMS seem less than fully engaged in making the EU's development acquis and these rules seem to have a low level of resonance with national beliefs on ODA policy. Norm entrepreneurs like domestic development NGO coalitions often only promote the EU norms which fit their interests. The European Commission (EC), which could also be conceived as a norm entrepreneur, has no clear strategy to promote socialization.

The contribution of the paper to the literature is threefold. First, the existence and effectiveness of socialization pressures in post-accession settings is still an under-researched topic, and development policy is an ideal case to examine them. Existing studies on Europeanization of NMS ODA policies only marginally explore the role of socialization (Lightfoot, 2010; Horky, 2012). Second, while there is now an emerging body of literature on development policies of the new member states, ${ }^{3}$ the dynamics of political decision making, as well as the factors which influence these are still not well understood. By opening the 'black box' of development policy making at the EU and the national level, the paper not only reveals important dynamics in EU development policy but also contributes to our understanding of intra-institutional and member state interactions in the Council and its Working Groups. Finally, the paper adds to the existing literature on the role of socialization

\footnotetext{
${ }^{3}$ See for example the edited volume by Horky-Hluchan and Lightfoot (2012).
} 
to promote Europeanization within the field of EU external relations. The following section presents the framework of the paper, as well as details on methodology and data collection. This is followed by the empirical section, which examines the making of the development acquis and issues affecting its implementation in the NMS.

\section{Europeanization and Social Learning in Development Policy}

The concept of Europeanization has been extensively used in the literature to explain why EU member states and candidate countries adopt or fail to adopt certain political provisions or policy-level regulations, norms or 'ways of doing things' advocated by the EU. The definition of Radaelli (2003: 30) is used, as modified by Moumoutzis (2011: 612): Europeanization is 'a process of incorporation in the logic of domestic discourse, political structures and public policies of formal and informal rules, procedures, policy paradigms, styles, "ways of doing things" and shared beliefs and norms that are first defined in the EU policy processes'. Europeanization is therefore understood in this paper as a top-down process, and issues related to bottom-up Europeanization, i.e. member states attempting to upload their policy agendas to the EU level, are beyond the scope of the paper. ${ }^{4}$ The two main mechanisms for explaining this rule adoption process are conditionality (based on rationalist institutionalism) and socialization (based on constructivist institutionalism), and have been documented extensively in the literature (see for example Checkel, 2001; Schimmelfennig and Sedelmeier, 2005; Juncos, 2011).

As 'foreign aid has served as a microcosm of donor states' foreign policies' (Hook 1995, p. 16), and during the accession negotiations development policy was a part of the chapter on external relations, it makes sense to use the Europeanization literature on EU foreign policy as a point of departure, even though development policy is more 'Communitized' than foreign policy in general. Using the socialization model to explore change at the national level has often been employed in the EU foreign policy literature (Smith, 2000; Tonra, 2001; Moumoutzis, 2011; Wong 2007), and most importantly it has been used on several occasions to study the foreign policies of the NMS as well (Pomorska, 2011; Bátora, 2012; Baun and Marek, 2013). Just like in the case of foreign policy, the relative lack of a legally binding acquis suggests that socialization can be the only mechanism to explain domestic level policy change induced by EU processes in the case of development policy as well (see Baun and

\footnotetext{
${ }^{4}$ There are examples of uploading, especially in the case of NMS transition experience that would merit further exploration.
} 
Marek, 2013). Development policy is a shared parallel competence between the EC and member states and the EC thus cannot legally influence the individual priorities of the member states. Sedelmeier (2011: 23) implies that the EU may rely more on socialization strategies to exert influence over its member states, as the lack of binding rules means that there is little direct conditionality.

The content of the acquis provides a second reason why socialization is a good approach to studying development policy. Much of the EU's development acquis relates to the common development policy and is thus not directly applicable in member states. However, there is a growing body of recommendations for the bilateral ODA policies of the members (Orbie, 2012). These recommendations, mainly in the form of Council Conclusions, form an extensive body of 'soft law' instruments that are not binding, 'but rest solely on their moral force' (Carbone, 2007 p. 50). The most important and frequently reiterated recommendations include the following:

- For NMS, increase aid spending to $0.33 \%$ of their gross national incomes (GNI) by 2015, and setting out an ODA growth path to achieve this (Council of the European Union, 2007);

- changing geographical aid allocation to devote more resources to Africa and least developed countries, while also recognizing the value of concentrating member state activities in areas and regions where they have comparative advantages (European Consensus, 2006);

- untying aid from exports (European Consensus, 2006);

- increasing policy coherence for development (Council of the European Union, 2012a);

- better coordination between the bilateral policies of member states (European Consensus, 2006),

- engaging in joint actions and multiannual programming with other donors (Council of the European Union, 2011a);

- reducing the number of countries and sectors supported in order to avoid fragmentation (Council of the European Union, 2011a);

- increasing transparency (Council of the European Union, 2011b).

- making increased use of the budget support modality (Council of the European Union, 2012b) 
Third, member state officials frequently interact with each other and the EU institutions on development policy issues, leading to a dense policy making setting which has been described to be conducive to socialization. Fourth, there is a strong presence of potential norm entrepreneurs, often linked to transnational epistemic communities in the policy area, which try to exert normative pressure on governments (see Denca, 2009). Fifth, other states experienced various degrees of socialization in this policy field post accession, notably Ireland and Spain. Alonso (2005 p. 497-8) argues that EU membership played a key role in the evolution of Spanish aid that saw Spain go from a recipient of aid in 1979 to be the $11^{\text {th }}$ largest donor of aid in 2003. The socialization of Spain can be seen as successful, as despite rollbacks due to the Euro-zone crisis, the country remains committed to development policy (OECD-DAC, 2011b). Finally, there is the specific aspect of Europeanization in postaccession settings. If accession conditionality was the main tool that induced behavioral changes among the new member states, compliance may decrease post accession thus weakening the EU's influence (Epstein and Sedelmeier, 2008; Sedelmeier 2011), leaving socialization as the only mechanism that can generate compliance.

The socialization model argues that actors will follow a logic of appropriateness, and they will adopt the relevant norms and laws not because they have to (as in the conditionality framework), but because these rules become internalized and a conviction gradually develops that they represent the only proper way to act (de Flers and Muller, 2010). A key argument in the socialization literature is that such convictions can develop even in face of opposing material interests, such as a lack of resources. The paper acknowledges that material interests and the lack of conditionality can play an important role in inducing non-compliance in the short term in NMS development policies, however, looking at material interests alone cannot tell the whole story. Scholars in the Europeanization literature have long argued however that the two models should not be seen as complementary, not mutually exclusive (Sedelmeier, 2011: 10). Short term non-compliance based on rational cost-benefit calculations does not mean that socialization processes cannot exist in parallel. Socialization, in spite of the material incentives, may induce behavioural change and the internalization of the EU's development norms among the NMS. One must explore the existence and strength of these socialization pressures to get the fuller picture on why the NMS (fail to) comply with the EU's development acquis.

Europeanization assumes that the main variable affecting national policy outcomes are adaptation pressures from the EU level. The literature on the aid performance of donors 
(Lancaster, 2007; Chong and Gradstein, 2008; Dang et al., 2013) however also looks at the influence of many other economic, social and political variables as well, many of which are internal to the donor countries, while also highlighting the need for strong adherence to internationally accepted development norms (van der Veen, 2011). Therefore, several further potential explanations are possible for the state of affairs in CEE ODA policies beyond material interests and socialization, most importantly the influence of various domestic interest groups. ${ }^{5}$ Domestic constituencies for aid in the NMS are weak (Szent-Iványi, 2012), leaving international pressure as the main potential source of policy change. None the less, the socialization model used in this paper has a strong explanatory power, as incorporates domestic actors and their influence on ODA policy outcomes, as well as social learning by these actors.

Turning to the question of compliance in the NMS, development policy is an especially interesting case in point. The EU conditionality prior to accession was characterized as a 'monologue not a dialogue'. ${ }^{6}$ During the accession negotiations, there was a provision that the acceding member states must set up ODA policies, but little direction was given on what this policy should include, how it should be organized and what level of resources the candidate countries should devote to it (Lightfoot, 2010). As a result, the creation of ODA policies was seen as a technical hurdle by the accession countries, albeit a hurdle with clear foreign policy connections, with few costs and little domestic opposition (Szent-Iványi and Tétényi, 2013). In the beginning EU pressure was 'important', but after accession the 'pressure is off' as 'no one is pushing from Brussels'. 'A quick glance at the bilateral development policies of the NMS reveals that they comply with very few of the recommendations contained in the acquis (Horky, 2012; Szent-Iványi, 2012). For example, the NMS channel a very small portion of their aid to Africa, most of their aid is tied to exports, they do not provide budget support, and there is no evidence of them taking part in joint programming efforts. This observation has led Szent-Ivanyi (2012) to argue that Hungarian officials have learned to 'talk the talk' of Brussels, whilst Horky (2012) adopts the term 'shallow' Europeanization.

\footnotetext{
${ }^{5}$ See for example Szent-Iványi (2012) which develops several potential explanations for the state of affairs in the case of Hungarian ODA policy.

${ }^{6}$ The authors thank Prof. Dave Allen for this observation.

${ }^{7}$ Interview with an MFA official from a NMS, 3 November 2009; and with an NGDO official, 26 July 2010.
} 
The paper focuses on understanding the socialization processes faced by the Ministries of Foreign Affairs (MFAs), as they are the most important actors in official bilateral development policies. As stated earlier, we utilise process tracing (see also Kittel and Kuehn 2013) to track how the EU's development acquis is made, perceived and implemented and how conducive this process is for socialization. We intend to identify how strongly the scope conditions for successful socialization are present, by tracing this rule making and implementing process. Scope condition can be grouped into two categories (Sedelmeier 2011: 13): international and domestic factors. International factors mainly refer to the legitimacy of the EU rules. The more legitimate EU rules are perceived, the more likely it is that actors will internalize them in the long term. According to Clark (2007: 196), legitimacy can either be derived from the process through which the rules are made (procedural legitimacy) or their normative content (substantive legitimacy). ${ }^{8}$ The first approach argues the rules will be perceived as legitimate, regardless of their content, if the process of rulemaking is seen as democratic, inclusive and participatory. Inclusiveness of the rule making process refers to the capacity of states to participate in a meaningful way rather than just their formal participation. The characteristics of the rule making process also matter beyond legitimacy. Socialization is more likely to occur in less politicized settings, and its likelihood also increases the more contacts member state officials have with the rule promoters (Lewis, 2005). The second approach derives legitimacy from the content of the rules: they will be seen as legitimate regardless of how they were made if they are normatively consistent, effective at a solving a given issue, are acted out in practice by authoritative actors, or a broader (beyond-the-EU) consensus exists on their appropriateness (Sedelmeier, 2011: 15).

Two issues are investigated in case of domestic factors. The first issue relates to policy resonance. How well do the specific rules advocated by the EU resonate with target country decision makers? Do they have any ingrained, prior beliefs on the issue? Are these compatible with EU rules? The second domestic factor is the presence of norm entrepreneurs, who themselves act as (additional) socializing agents and try to educate the governments. Such norm entrepreneurs in the case of development policy may be the EC, the OECD Development Assistance Committee (DAC) or national Non-Governmental Development Organisations (NGDOs) and any EU-wide epistemic community they may be linked to. The gradual internationalization of the norms embodied in the EU's development acquis in the new member states can be difficult to identify. While elite interviews are the only way to gain

\footnotetext{
${ }^{8}$ The authors thank Prof. Jason Ralph for this observation.
} 
information on changing perceptions and identities, these changes are difficult to tease out (Lewis, 2005). Any shift in allegiances will take time, elites may stick to official rhetoric in interviews, and even when identity changes are apparent, they may not confess it (or they may not even be aware of it). ${ }^{9}$ Understanding the scope conditions that make socialization likely is therefore a more fruitful approach than explicitly testing gradual changes in elite identities. The most important sources of data are 42 qualitative interviews carried out between 2008 and 2013. People interviewed included current and former development diplomats at the permanent representations to the EU of the four countries, senior MFA officials in the respective capitals, officials from the Commission, the Council Secretariat and the European External Action Service (EEAS), as well as representatives of the national NGDO platforms and leading NGDOs. The interviewees remain anonymous due to reasons of confidentiality. ${ }^{10}$ Data collected through the interviews was triangulated using official documents from the CEE countries on development strategies, as well as evaluations carried out by the OECD DAC and national NGDO platforms.

\section{Socialization along the Development Policy Making Process}

\section{The nature and making of the development acquis}

As mentioned, the EU's development acquis includes a wide range of recommendations for member states to implement in their national ODA policies. These recommendations are proposed by the EC in the form of Commission Communications, which basically provide a draft text for the member states to discuss in the Council. The final outcomes are - with very few exceptions - in the form of Council Conclusions, and carry no explicit legal obligations for the member states to transpose them to their domestic legislation or base national policies on them. The wordings in the Council Conclusions clearly hint at this non-compulsory nature, with phrases like 'Member States are invited to develop or review their own guidelines in the light of these Council Conclusions [...]' (Council of the European Union, 2012b, p. 4) being common.

\footnotetext{
${ }^{9}$ Wong and Hill (2011) outline a number of specific issues raised by utilizing interviews for Europeanization research. However, the large number of interviews relative to the number of people working in ODA in the NMS, as well as triangulation with other data sources provides soundness to the conclusions.

${ }^{10}$ Given the small number of people working in international development policies in the NMS and that interviewees may be identifiable even if anonymized, details on the nationalities of interviewees or the location of the interviews when citing interview data are not provided.
} 
The rule making process may have important socializing effects on the members, both in terms of its perceived legitimacy and beyond. While it is the Council that makes the final and formal decision on the EU's development acquis, it is the Council Working Group on Development (CODEV) that makes the actual decisions in the broad majority of the cases. CODEV is composed of specialized diplomats from the member state permanent representations in Brussels, and prepares the development-related agenda of the Committee of Permanent Representatives (COREPER) and thus ultimately the Council. CODEV meets at least once a week, and many of the member state diplomats (especially in case of smaller states) also represent their countries in other Council working groups, thus they interact frequently. The work of CODEV, which spans a wide range of strategic level issues, from sexual reproductive rights to the developmental impact of trade, was described as 'rather informal', friendly, co-operative and consensus-driven group by member state diplomats and EU officials, although member states do have 'red lines'. ${ }^{11}$ Thus, CODEV appears to be a forum conductive to socialization. CODEV is chaired by the rotating presidency, but much of its agenda is driven by the EC, and increasingly since the Lisbon Treaty, the EEAS. There is an informal goal to reach an agreement on the policy issues discussed, thus dossiers rarely go undecided to COREPER. Member states can be grouped into three groups in CODEV, depending on the issue. The first group of states behave as passive observers, with no interests at stake in the given issue, or expertise on it. These states often only use the group as a platform for learning and getting information on the topic. The second group of states will most likely drive the discussion as they have a strong interest in the issue and significant expertise. The third group is composed of states that do care for the issue and have some red lines, but will not drive the debate. ${ }^{12}$

How the NMS perceive the workings of CODEV and how meaningfully they are involved in its work are important elements when it comes to evaluating the perceived procedural legitimacy of rule making in CODEV. During the interviews, a number of themes emerged that suggest less than full participation, which may have an impact on perceived legitimacy and thus openness to socialization. First, NMS almost never drive the issues in CODEV, only occasionally falling into the third group of 'carers' and in most cases are only passive observers. ${ }^{13}$ One NMS diplomat noted that the work of this group does not really concern

\footnotetext{
${ }^{11}$ Interview with an EC DG Development official, 21 January 2013.

${ }^{12}$ Interview with an official from the EEAS, 23 January 2013.

${ }^{13}$ Interview with an official from the Council Secretariat, 22 January 2013.
} 
them, but it is 'interesting none the less' ${ }^{14}$ Another argued that his country has little to contribute as they are not doing anything in the issue area. ${ }^{15}$ An official from the EEAS noted that the NMS 'tend to be on the quieter side, while representatives from the UK or France tend to talk a lot ${ }^{16}$.

The second theme has to do with the capacities of the NMS to participate fully in the work of CODEV. Representatives from the NMS rarely receive detailed instructions from their capitals. Whilst this is not unusual in foreign policy (see Juncos and Pomorska, 2011; Chelotti, 2013), the NMS have additional problems in the field of development that exacerbate the problem. These include low policy staff numbers at MFAs, which means that they simply cannot react to all the issues discussed in CODEV and in many cases think it is unnecessary to do so, as no national interest is at stake. ${ }^{17}$ Contrast this with CODEV representatives from established donors like Sweden, who receive detailed instructions on almost every issue discussed. Also, large older member states (OMS) can often afford to have a separate diplomat for every Council working group, while the CODEV representative of smaller NMS typically has other additional tasks.

The third theme relates to the backgrounds of NMS CODEV representatives. While CODEV reps from the OMS generally have a strong development background, those from the NMS are usually career diplomats. Critics highlight that the diplomatic practice of rotation gives them a shorter time perspective as they will only be in post three years (Horky, 2012). In addition, much of their tenure in CODEV must be devoted to learning the ropes from scratch, thereby making them less effective. ${ }^{18}$ Evidence from the interviews suggests that some form of social learning is taking place in the build up of institutional memory within the NMS because, as one EU official noted 'every new [NMS] representative is a bit better than the previous one was when (s)he had been new', in a sense that they have better understandings of development issues and more knowledge on how development policy works. None the less examples such as this still exist: 'I struggle getting feedback, and this has several factors: [...] there is a lack of capacity, recently we have had a cut in personnel, the fact that I have to

\footnotetext{
${ }^{14}$ Interview with a diplomat from a NMS, 22 January 2013.

${ }^{15}$ Interview with a diplomat from a NMS, 25 April 2013.

${ }^{16}$ Interview with an official from the EEAS, 23 January 2013.

${ }^{17}$ Interview with a diplomat from a NMS, 23 January 2013.

${ }^{18}$ Interview with an NGDO official, 26 July 2010.
} 
cover such a wide range of issues with no experience in this field, and no one has done me a handover'. ${ }^{19}$

Fourth, while NMS seem to be novices, they rarely ask for advice from other (old) member states or from the EC and the EEAS, even though asking for advice and conducting informal discussions seem to be very much the norm in CODEV. ${ }^{20}$ One interviewee highlighted the 'closed doors within ministries' when it came to learning from the EU. ${ }^{21}$ Also, NMS diplomats make much less use of networking opportunities and are not seen as often on EC organized events outside of CODEV than diplomats from the OMS do. ${ }^{22}$ Some NMS diplomats clearly felt that they are treated as outsiders in the policy area by both the OMS and the EC.

Fifth, NMS seem to place a large emphasis on 'transition experience' and the Eastern neighbourhood (Non-paper, 2011). This was seen to be an area where they have comparative advantages over other donors, although there was a feeling among EU officials that they do this at the expense of the myriad of other issues discussed in CODEV. One EU official actually called this an 'obsession' with transition experience. ${ }^{23}$ Most NMS diplomats interviewed argued that the EU should make greater use of their transition experience as it was true value added, but there seems to be a feeling that OMS are not only not convinced by this argument, but are often irritated by how NMS diplomats always return to this mantra.

Sixth, there are issues on which recurring political tensions exist between the NMS and the OMS. Beyond transition experience, one such issue is the Eastern Neighbourhood. While the NMS would be keen on providing more support to the region, the older members, especially the UK and France, see these efforts as threats to the EU's focus on Sub-Saharan Africa. NMS have also been lobbying for preferential treatment in aid project implementation tenders for their national NGDOs, which the older members oppose.

These six themes may have an impact on how the NMS perceive the procedural legitimacy of rulemaking in CODEV. Potential socialization is weakened by their lower capacities and lower interest (aside from some specific niche issues like transition experience) to participate

\footnotetext{
${ }^{19}$ Interview with a NMS diplomat, 31 October 2008.

${ }^{20}$ Interview with an EC DG Development official, 21 January 2013.

${ }^{21}$ Interview with a NMS diplomat, 1 April 2011.

22 Interview with an EC DG Development official, 21 January 2013.

${ }^{23}$ Interview with an official from the Council Secretariat, 22 January 2013.
} 
in making the development acquis, and there seems to be a feeling of being outsiders in this policy area with little to contribute.

Turning to the substantive legitimacy of the development acquis, this can be seen as strong and difficult for any country to dispute, even the NMS. For one, the main goal of the development acquis is to increase the effectiveness of the EU's development efforts through greater strategic guidance, coordination and joint initiatives, thereby reducing global poverty. The fragmentation of donors and the lack of coordination among them increases the costs of foreign aid, places large administrative burdens on recipients and leads to wasteful parallel efforts. Counter-arguments that donor pluralism has its merits are in a clear minority (Frot and Santiso, 2010). The rules embodied in the acquis can therefore be seen as normatively consistent. There is also a broader, 'beyond-the-EU' consensus on much of the rules, as major parts of the development acquis can be seen as an EU-level translation of global initiatives. The fundamentals of the acquis are clearly linked to Millennium Development Goals and quantitative aid targets are derived from the Monterrey Consensus (Orbie, 2012). The rules aimed at increasing aid effectiveness link in to the global aid effectiveness agenda, such as the Paris Declaration, the Accra Agenda and the Busan Partnership. There are voices examining whether the EU is the best possible forum for donor coordination (see Maxwell et al., 2010 for a discussion), yet it cannot be disputed that the EU, as one of the largest global donors, has done the most in practice by undergoing a spectacular transformation in the past decades to become a rather effective aid agency (Carbone, 2007). There is always room for improvements of course, like a recent report by the European Court of Auditors (2010) showed in the case of budget support, but the general direction of EU development practice is clearly towards improving the effectiveness of aid in reducing poverty. All these factors suggest substantive legitimacy of the EU's development acquis is strong, something no NMS official interviewed disputed. Rather they questioned the acquis' appropriateness for their national policy contexts. This however has more to do with resonance, one of the domestic issues we turn to next.

\section{National implementation of the development acquis}

Once a Council Conclusion is released, how does it enter national policy making? The general impression emerging is that the NMS rarely make use of these documents. According to one diplomat interviewed, 'there is nothing to implement on Council Conclusions, as they 
are not law'. ${ }^{24}$ Other statements are also telling: 'the Conclusions are used as a source of inspiration, ${ }^{25}$ or help 'fine tune' national policy documents. Others interviewees were not even aware that Council Conclusions often include recommendations for bilateral development policies and thought they exclusively refer to the common development policy. None of the four MFAs have formal procedures for debating Council Conclusions and channeling them into domestic policymaking. Legal and policy documents in the NMS usually make some vague reference to the EU level, and the Czech Republic and Slovakia even explicitly mention the European Consensus as containing principles which influence the country's development policy. Beyond these references, it is very difficult to find examples of specific acquis transposed into domestic legislation or strategies. Any actual impact beyond this rhetoric is even more dubious. As an EC official put it, '[the NMS] tend to forget the European dimension'. ${ }^{26}$

NMS see little need to channel Council Conclusions into national policies due to low policy resonance stemming from prior, ingrained beliefs on development policy. These beliefs run against many of the norms set out in the various EU documents listed in the previous section. Almost all MFA representatives voiced concerns as to how relevant the EU recommendations are for their contexts, or even argued outright that they are unsuitable for the realities in the NMS. Budget support was one of the most frequently mentioned examples. ${ }^{27}$ The EU pushes for increased usage of this modality based on the grounds that it is more effective (Council of the European Union, 2012b). The NMS however resist using budget support claiming that it would lead to decreasing visibility of their efforts and that they would have little influence on how the money is actually spent. Another example is joint programming, an issue which the EU promotes as the main tool for donor coordination and reducing donor fragmentation (Council of the European Union, 2011a). NMS diplomats argue that their countries have little capacities in the field, and as they could only contribute relatively small resources to joint programs, they would have little influence on how the programs are designed and implemented. A pilot initiative for joint actions in Moldova, organized by the EC in 2011-12, provides an example of this reluctance for working together. Some NMS, such as Hungary

\footnotetext{
${ }^{24}$ Interview with a diplomat from a NMS, 23 January 2013.

${ }^{25}$ Interview with a diplomat from a NMS, 21 January 2013.

${ }^{26}$ Interview with an EC DG Development official, 21 January 2013.

${ }^{27}$ Budget support involves the transfer of resources directly to the recipient's budget, giving the recipient government much larger discretion in deciding what to spend the money on.
} 
abstained from it totally, while the involvement of others was characterized as unenthusiastic and low-key.

While resistance to implementing the acquis in the issues above may stem from material interests, often the lack of money, these arguments have also become strong ingrained narratives which no ministry official was willing to question. Material interests alone cannot explain why these beliefs were uniformly strong in all four NMS, even when some of them, like the Czech Republic, have significantly higher per capita spending on ODA than others. Material interests also cannot explain why in light of the financial crisis aid spending remained relatively constant. There is thus only limited evidence of resonance with most of the EU rules, highlighting that Socialization may be difficult in face of such strong ingrained beliefs.

National NGDOs form an important group of norm entrepreneurs that can play a role in gradually changing these beliefs by lobbying governments and also pressing for the implementation of EU rules. NGDOs in all four countries created advocacy platforms in the early 2000 s in order to speak with a single voice towards the government, and EU accession has done much to strengthen them by providing them access to EU financing and membership in wider epistemic communities such as the EU-wide development NGDO network CONCORD. ${ }^{28}$ The NGDO platforms clearly make efforts to influence their national government, enjoying as they do special consultative status with their respective governments and producing regular 'Aidwatch' reports on the government's activities. NGDOs act as watchdogs, but are also beneficiaries of government funds as implementers of development projects. This fact makes their advocacy work Janus-faced, which becomes clear when looking at national Aidwatch reports. While in principle they lobby governments to increase development effectiveness, they rarely mention issues which could harm their access to government funding, such as budget support. Hungarian NGDOs for example talk rather vaguely about increasing aid quality, without going into details on exactly how (HAND, 2011). Czech NGDOs mainly focus on rather technical issues when discussing aid quality like publishing tender forecasts (FORS, 2012). NGDOs do however seem highly committed to increasing bilateral aid, and refer to the $0.33 \%$ target of the acquis frequently. This 'selectiveness' in which aspects of the acquis to promote and which not can make one

\footnotetext{
${ }^{28}$ Interviews with representatives from NMS NGDO platforms (10 April 2008, 4 February 2013, 5 March 2013) and CONCORD (23 January 2013).
} 
question just how much NGDOs can be conceptualized as norm entrepreneurs as opposed to self-interested agents.

The EC itself can also be thought of as a potential norm entrepreneur. As the initiator of the acquis, it could be logical to assume that it would promote actual implementation as well. Indeed, the EC has developed some tools to assist the NMS in implementation and through this also provide additional channels for socialization. There is a weekly breakfast meeting between NMS CODEV representatives and EC officials, and the EC has also been running several 'capacity building' schemes for the NMS, which focus mostly on technical training, but the 2011-12 round attempted a more practical approach with the joint actions in Moldova mentioned above. ${ }^{29}$ Capacity building however is to be phased out soon. Opinions on what role the EC should play greatly diverged. Some NMS diplomats complained that the EC is not doing enough to help the NMS, and does not show an understanding of their problems. ${ }^{30}$ Others argued that the capacity building offered is very 'light' and a more hands on approach would be needed. ${ }^{31}$ It was also mentioned that EC assistance has been rather marginal compared to capacity building initiatives from other organizations like the United Nations Development Program. ${ }^{32}$ EC officials on the other hand argued that they cannot force things, and it is ultimately the responsibility of the NMS to implement what they had agreed to. The Commission 'presents examples but it is entirely flexible; countries can choose their own path'. ${ }^{33}$ Whatever the merits of this argument, the EC does not seem to have any explicit strategy to socialize the NMS, and seems unwilling to engage in one.

A third norm entrepreneur is the OECD DAC, which is charged with collecting statistics on ODA, as well as spreading best practices between members. The four NMS were only observers of the DAC up to 2013. While the DAC has its own agenda and set of recommendations of its own for member states and candidates, these are also rooted in the global aid consensus and are thus highly similar to what is contained in the EU acquis. Besides offering training and opportunities for informal learning, the most high profile tool of the DAC for educating the NMS have been the 'special peer reviews' (OECD, 2007; 2009; 2011a). These reviews evaluate the development policy of the country and contain a number

\footnotetext{
${ }^{29}$ Interview with an EC DG Development official, 21 January 2013.

${ }^{30}$ Interview with a diplomat from a NMS, 23 January 2013.

${ }^{31}$ Interview with a diplomat from a NMS, 21 January 2013.

${ }^{32}$ Interview with a diplomat from a NMS, 19 March 2012.

${ }^{33}$ Interview with an EC DG Development official, 29 October 2008.
} 
of recommendations for future reform, most of which are highly compatible with the EU acquis. The DAC has published such reviews for the Czech Republic, Poland, and Slovakia, but the actual impact of the special reviews is questionable. They are either totally ignored in some of the countries, ${ }^{34}$ or only the more technical recommendations are acted upon. One exception is the review of the Czech Republic (OECD, 2007), which most likely had an impact on the transformation of the institutional structure of ODA in the country in 2009 which led to the centralization of the ODA budget in the MFA. Recommendations however on increasing aid levels, increasing aid effectiveness by employing the principles of the Paris Declaration, or reducing the fragmentation of allocation went largely ignored.

\section{Conclusions}

This paper has hypothesized that long term compliance with the EU's development acquis in the NMS has been weak due to the unconducive environment for socialization. The Czech Republic, Hungary, Poland and Slovakia have been donors of foreign aid and members of the EU for a decade now. These ten years plus of interactions might lead to expectations that some socialization must have taken place, even though the EU has few legally binding rules on member state development policies (see Horky, 2012). Any Europeanization however seems rather shallow and superficial. The lack of conditionality or material incentives can only partly explain the feeling that the NMS are 'reluctant donors'. The paper has argued that few possibilities for socialization exist in the current processes of how development policy is made both on the EU and member state level. Examining the scope conditions which make socialization more likely, it is only the strong substantive legitimacy of the development acquis which could promote a change in values and beliefs. All other factors seem to go against this and limit the possibilities for socialization. Due to lower capacities and lower interest in development policy, NMS are rather passive in making the development acquis, which decreases its perceived procedural legitimacy. MFAs have no formal methods for channeling the acquis into national policies, which reflects the fact that they perceive much of it to be inappropriate for their situation. Resonance between the EU acquis and national beliefs is clearly low. Last but not least, there are no norm entrepreneurs that clearly and consistently try to educate governments and promote the implementation of principles embodied in the acquis. The OECD DAC may be an exception, but its recommendations often go ignored.

\footnotetext{
${ }^{34}$ Interview with a diplomat from a NMS, 22 January 2013.
} 
The conclusion contained in much of the literature that socialization in EU foreign policy is weak is supported by our research on the NMS ODA policies. Reviewing the DAC peer reviews and various NGDO Aidwatch reports shows that many member states see the development acquis as a menu from which they choose the aspects that suit their bilateral aid policies. Even Spain and Austria, which have made significant steps to approximate their ODA policies to principles embodied in the EU acquis, have important shortcomings. None the less, recent OECD DAC's peer reviews (see OECD, 2009) clearly show that many of the EU-15 have indeed carried out significant reforms in their ODA policies in the past 10 years with a view of initiating changes similar to those in the acquis (such as cutting the number of partners and sectors in Ireland, the Netherlands and Sweden, increasing ODA spending in the UK, increasing aid allocated to the poorest countries by Austria, Ireland or France, or making poverty reduction a stated goal in several donors), which may be results of different ingrained beliefs due to different historical trajectories (such as having a colonialist past) or stronger public support for development effectiveness leading to more consistency in the activity of norm entrepreneurs. Socialization may also take longer time to happen than the 10 years the NMS have had. There is clearly more scope here for comparative research.

An important conclusion for the wider Europeanization literature relates to the role played by the European Commission. The case of development policy shows that there is a clear potential, and perhaps also demand for the EC to take a more assertive role as a norm entrepreneur. The issue of weak socialization must be faced up to by the EC, and it should reconsider its current stance against engaging in more active socialization strategies. The fact that the Czech Republic, Poland and Slovakia joined the DAC in 2013 may provide more international socialization pressures, which could in turn reinforce weak Europeanization processes. On the other hand, the DAC they joined is now struggling to maintain its relevance in a highly evolving international development landscape, with new donors like China, Brazil, Russia or India offering alternatives to developing countries. The challenge of emerging donors also provides an answer as to why the EC should care about socializing the new members. If Europe is to maintain its influence in the developing world, particularly post 2015 , it must act in a more concerted and coherent way, and having 'reluctant' donors that do not totally share the common view of development policy fatally weakens this unity.

\section{References}


Alonso, J.A. (2005) 'Spanish Foreign Aid: Flaws of an Emerging Framework.' In Hoebink, P. and Stokke, O. (eds) Perspectives on European Development Co-operation (London: Routledge), pp. 493-517.

Bátora, J. (2012) 'Europeanization of Foreign Policy: Whither Central Europe?’ In Šabič, Z. and Drulák, P. (eds): Regional and International Relations of Central Europe (London: Palgrave), pp. 220-238

Baun, M. and Marek, D. (eds) (2013) The New Member States and the European Union: Foreign policy and Europeanization (Abingdon: Routledge).

Carbone, M. (2007) The European Union and International Development (London: Routledge/UACES).

Checkel, J.T. (2001) 'Why Comply? Social Learning and European Identity Change.' International Organization, Vol. 55, No. 3, pp. 553-88.

Chelotti, N. (2013) 'Analysing the Links between National Capitals and Brussels in EU Foreign Policy'. West European Politics, Vol. 36, No. 5, pp. 1052-1072.

Chong, A. and Gradstein, M. (2008) 'What determines foreign aid? The donors' perspective.' Journal of Development Economics, Vol. 87, No. 1, pp. 1-13.

Clark, I. (2007) 'Legitimacy in International or World Society'. In Hurrelmann, A., Schneider, S. and Steffek, J. (eds) Legitimacy in an Age of Global Politics (New York: Palgrave Macmillan), pp 193-210.

Council of the European Union (2007) 'Conclusions of the Council On Keeping Europe's promises on Financing for Development.' 9556/07, 15 May.

Council of the European Union (2011a) 'Operational Framework on Aid Effectiveness Consolidated text.' 18239/10, 11 January.

Council of the European Union (2011b) 'EU Common Position for the Fourth High Level Forum on Aid Effectiveness' 14 November.

Council of the European Union (2012a) 'Council conclusions on Policy Coherence for Development.' 14 May.

Council of the European Union (2012b) 'Council conclusions 'The Future Approach to EU Budget Support to Third Countries.' 14 May. 
Dang, H., Knack, S., and Rogers, H. (2013) 'International aid and Financial crises in donor countries.' European Journal of Political Economy, Vol. 32, pp. 232-250.

de Flers, N. and Müller, P. (2012) 'Dimensions and Mechanisms of the Europeanization of Member State Foreign Policy: State of the Art and New Research Avenues.' Journal of European Integration, Vol. 34, No. 1, pp. 19-35.

Denca, S.S. (2009) 'The Europeanization of Foreign Policy: Empirical Findings From Hungary, Romania and Slovakia', Journal of Contemporary European Research, Vol. 5, No. 3, pp. 389-404.

Epstein, R.A. and Sedelmeier, U. (2008) 'Beyond conditionality: international institutions in postcommunist Europe after enlargement.' Journal of European Public Policy, Vol. 15, No. 6, pp. 795-805.

European Consensus (2006) 'Joint declaration by the Council and the representatives of the governments of the Member States meeting within the Council, the European Parliament and the Commission on the development policy of the European Union entitled The European Consensus.' Official Journal C 46 of 24 February.

European Court of Auditors (2010) 'The Commission's management of general budget support in ACP, Latin American and Asian Countries.' Special Report No 11.

FORS (2012) Briefing paper: Official Development Assistance of the Czech Republic in 2011 (Prague: FORS).

Frot, E. and Santiso, J. (2010) 'Crushed Aid: Fragmentation in Sectoral Aid.' OECD Development Centre Working Papers, No. 248.

HAND (2011) A magyar NEFE a valsag eveiben. (Budapest: HAND).

Hoebink, P. and Stokke, O. (eds) Perspectives on European Development Co-operation (London: Routledge).

Hook, S. (1995) National Interest and Foreign Aid (Boulder: Lynne Rienner).

Horky, O. (2012) 'The impact of shallow Europeanization of the new member states on the EU's actorness: what coherence between foreign and development policy?' In Grimm, S., Makhan, D. and Gänzle, S. (eds) The European Union and Global Development - An Enlightened Superpower in the Making? (London: Palgrave), pp. 17-36. 
Horký-Hluchan, O. and Lightfoot, S. (2012) From Aid Recipients to Aid Donors.

Development Policies of Central and Eastern European States (London: Routledge).

Juncos, A.E. (2011) 'Europeanization by Decree? The Case of Police Reform in Bosnia'. Journal of Common Market Studies, Vol. 49, No. 2, pp. 367-387.

Juncos, A.E. and Pomorska, K. (2011) 'Invisible and unaccountable? National Representatives and Council Officials in EU foreign policy'. Journal of European Public Policy, Vol. 18, No. 8, pp. 1096-1114.

Kittel, B. and Kuehn, D. (2013) 'Introduction: Reassessing the Methodology of Process Tracing'. European Political Science, Vol. 12, No. 1, pp. 1-9.

Lancaster, C. (2007) Foreign Aid: Diplomacy, Development, Domestic Politics (Chicago: University of Chicago Press).

Lewis, J. (2005) 'The Janus Face of Brussels: Socialization and Everyday Decision Making in the European Union.' International Organization, Vol. 59, No. 4., pp. 937-71.

Lightfoot, S (2010) 'The Europeanisation of International Development Policies: The Case of Central and Eastern European States'. Europe-Asia Studies, Vol. 62, No. 2, pp. 329-350.

Maxwell, S., Gavas, M., Barder, O., Johnson, D. (2010) 'Global governance of the aid system and the role of the European Union.' ODI Briefing Paper.

Moumoutzis, K. (2011) 'Still Fashionable Yet Useless? Addressing Problems with Research on the Europeanization of Foreign Policy.' Journal of Common Market Studies, Vol. 49, No. 3, pp. 607-629.

Non-paper (2011) Harnessing the transition experience in EU's external relations: From policy to implementation. Non-paper by the Czech Republic, Estonia, Hungary, Latvia, Lithuania, Romania, Slovak Republic, and Slovenia. Available at http://www.mzv.cz/file/591175/non paper_on the transition_experience.pdf, accessed 2 February 2011.

OECD (2007) DAC Special Review of the Czech Republic (Paris: OECD).

- (2009): Managing aid : practices of DAC member countries (Paris: OECD).

-(2010). DAC Special Review of Poland (Paris: OECD).

-(2011a) DAC Special Review of the Slovak Republic (Paris: OECD). 
- (2011b) DAC Review of Spain (Paris: OECD).

Orbie, J. (2012) 'The EU as an actor in development: Just another donor, European norm maker, or eclipsed by superpower temptations?', in Grimm, S., Makhan, D. and Gänzle, S. (eds) The European Union and Global Development - An Enlightened Superpower in the Making? (London: Palgrave), pp. 17-36.

Pomorska, K. (2011) 'Poland: Learning the Brussels Game.' In Wong, R. and Hill, C. (eds) National and European foreign policies: toward Europeanisation (London: Routledge). Radaelli, C.M. (2003) 'The Europeanisation of Public Policy'. In Featherstone, K. and Radaelli, C.M. (eds) The Politics of Europeanisation (Oxford: Oxford University Press).

Schimmelfennig, F. and Sedelmeier, U. (2005) 'Introduction. Conceptualizing the Europeanization of Central and Eastern Europe.' In Schimmelfennig, F. and Sedelmeier, U. (eds) The Europeanization of Central and Eastern Europe (Ithaca, NY: Cornell University Press), pp. 1-28.

Sedelmeier, U. (2011) 'Europeanisation in new member and candidate states'. Living Reviews in European Governance, Vol. 6, No. 1.

Smith, M.E. (2000) 'Conforming to Europe: the domestic impact of EU foreign policy co Operation', Journal of European Public Policy, Vol. 7, No. 1, pp. 613-631.

Szent-Iványi, B. (2012) 'Hungarian international development co-operation: context, stakeholders and performance.' Perspectives on European Politics and Society, Vol. 13, No. 1 , pp. 50-65.

Szent-Iványi, B. - Tétényi, A. (2013) 'The East-Central European New Donors: Mapping Capacity Building and Remaining Challenges.' Journal of International Development, Vol. 25, No. 6, pp. 819-831.

Tonra, B. (2001) The Europeanisation of National Foreign Policy: Dutch, Danish and Irish Foreign Policy in the European Union (Ashgate: Aldershot).

Van der Veen, A.M. (2011) Ideas, Interests and Foreign Aid (Cambridge: Cambridge University Press).

Wong, R. (2007) 'Foreign Policy.' In Graziano, P. and Vink, M. (eds) Europeanization: New Research Agendas (Basingstoke: Palgrave Macmillan). 
Wong, R. and Hill, C. (eds) (2011) National and European foreign policies: toward Europeanisation (London: Routledge). 